\title{
Effect of different $1 \%$ chlorhexidine varnish regimens on biochemical composition of the dental biofilm
}

\section{Efeito de diferentes posologias do verniz de clorexidina a $1 \%$ na composição bioquímica do biofilme dentário}

\begin{abstract}
Purpose: This investigation evaluated in a randomized controlled study the effect of different $1 \%$ chlorhexidine varnish $(1 \% \mathrm{CHX}-\mathrm{V})$ regimens on biochemical composition of the dental biofilm.

Methods: Subjects with mutans streptococci $\geq 10^{5} \mathrm{CFU} / \mathrm{mL}$ saliva, were allocated into 4 groups: A - single 1\% CHX-V application; B - 1\% CHX-V was applied once daily on 3 consecutive days; C - 1\% CHX-V was applied 3 times with an interval of 4 days between each application; and D - placebo varnish was applied once daily on 3 consecutive days. Dental biofilm samples were collected at baseline and 1, 4, and 8 weeks after the final varnish application and evaluated for inorganic phosphate and insoluble polysaccharide concentrations.

Results: No difference was observed between all groups during the different experimental periods in relation to biochemical composition. After 1 week, a significant increase was observed in inorganic phosphate concentration, returning to baseline values after 4 weeks. All groups showed a significant decrease in insoluble polysaccharide concentration for more than 8 weeks after treatment.

Conclusion: Varnish application resulted in modification of the dental biofilm toward a less cariogenic one.
\end{abstract}

Key words: Chlorhexidine; dental biofilm; inorganic phosphate; insoluble polysaccharide

\section{Resumo}

Objetivo: Este estudo avaliou o efeito de diferentes posologias do verniz de clorexidina a $1 \%$ ( $\mathrm{V}-\mathrm{CHX} 1 \%)$ na composição bioquímica do biofilme dental.

Metodologia: Voluntários com níveis de Streptococcus mutans $\geq 10^{5} \mathrm{UFC} / \mathrm{mL}$ saliva, foram divididos em 4 grupos: A - uma única aplicação do V-CHX1\%; B - aplicações de 1x/dia do V-CHX1\% durante 3 dias consecutivos; C - 3 aplicações de $1 \times /$ dia do $\mathrm{V}$-CHX1\% com intervalos de 4 dias entre elas; $D$ - aplicações de $1 x /$ dia do verniz placebo durante 3 dias consecutivos. Amostras de biofilme dental foram coletadas, no início e após 1, 4 e 8 semanas das aplicações dos vernizes, e analisadas quanto às concentrações de fosfato inorgânico $\left(P_{i}\right)$ e polissacarídeos insolúveis (PI).

Resultados: Não foram observadas diferenças, em relação à composição bioquímica, entre os grupos durante os diferentes períodos experimentais. Foi observado, após 1 semana, um aumento significativo nas concentrações de $\mathrm{P}_{\mathrm{i}}$, retornando aos valores iniciais após 4 semanas. Todos os grupos apresentaram uma redução significativa na concentração de PI por mais de 8 semanas após os tratamentos.

Conclusão: A aplicação do verniz resultou em uma modificação do biofilme dentário tornando-o menos cariogênico.

Palavras-chave: Clorexidina; biofilme dental; fosfato inorgânico; polissacarídeos insolúveis

\section{Luciana Gazaniga Maia Ribeiro \\ Marisa Maltz 。 \\ Lina Naomi Hashizume ${ }^{\circ}$}

a Department of Preventive and Social Dentistry, Faculty of Dentistry, Federal University of Rio Grande do Sul, Porto Alegre, RS, Brazil

Correspondence:

Lina Naomi Hashizume

Departamento de Odontologia Preventiva e Social Faculdade de Odontologia da Universidade Federal do Rio Grande do Sul

Rua Ramiro Barcelos, 2492 - Bom Fim

Porto Alegre, RS - Brasil

90035-003

E-mail: Ihashizume@yahoo.com

Received: May 10, 2010

Accepted: November 22, 2010

Conflict of Interest Statement: The authors state that there are no financial and personal conflicts of interest that could have inappropriately influenced their work.

Copyright: () 2011 Ribeiro et al.; licensee EDIPUCRS This is an Open Access article distributed under the terms of the Creative Commons AttributionNoncommercial-No Derivative Works 3.0 Unported License. 


\section{Introduction}

One strategy for controlling dental caries in patients with high levels of cariogenic microorganisms is their suppression by chemotherapeutic agents (1-3). Chlorhexidine (CHX) is an antimicrobial agent used extensively in dentistry. The importance of mutans streptococci (MS) in the etiology of dental caries has been clearly established $(4,5)$ and among dental biofilm microorganisms, MS are one of the most sensitive to $\mathrm{CHX}$ (6).

Although most studies have focused on the microbiological composition of the dental biofilm, the concentration of calcium, inorganic phosphate, fluoride, and extracellular insoluble polysaccharides is also related to its cariogenicity. The dental biofilm formed in the presence of frequent sucrose exposition ( 8 times per day) showed 3 times more extracellular insoluble polysaccharide and lower inorganic concentration of calcium, phosphoate, and fluoride than the control group (no sucrose exposure) (7). Mattos-Graner et al. (8) showed that caries incidence in children is more dependent on the capacity of MS to synthesize extracellular insoluble polysaccharide than on their number in the dental biofilm.

There are several vehicles used for CHX delivery, such as dentifrices, solutions, gels and varnishes (9-12). The latter were specially designed as a slow-release CHX agent, with the purpose of maintaining therapeutic concentrations over a period of several days (13). The varnish containing $1 \% \mathrm{CHX}$ has been investigated the most. However, there is no agreement with respect to the total number of $1 \% \mathrm{CHX}$ varnish applications (ranging from 1 to 3 ) and the interval between them (ranging from 1-7 days or monthly) (14-16).

No consensus has been reached in the literature about the ideal regimen of $1 \% \mathrm{CHX}$ varnish applications and there is no published data about its effect on the biochemical composition of the dental biofilm. The aim of the present investigation was to use a randomized controlled study to evaluate the effect of different regimens of topical application of a varnish containing $1 \% \mathrm{CHX}$ on the biochemical composition (inorganic phosphate and insoluble polysaccharide) of the dental biofilm.

\section{Methods}

One hundred and fifty-eight schoolchildren were screened for MS salivary levels. Those patients with $\mathrm{MS} \geq 10^{5} \mathrm{CFU} / \mathrm{mL}$ saliva (colony forming units per milliliter of saliva) in 2 saliva samples were invited to participate in the study. Sixty subjects, 11-16 years old (mean $\pm \mathrm{SD}, 12.9 \pm 1.39$ years old), were stratified according to the MS levels and randomly allocated in four groups according to varnish treatment. Five of the children left school. Therefore, the final sample comprised 55 subjects. The product used in this study was a varnish containing $1 \%$ chlorexidine and $1 \%$ thymol (Cervitec $^{\mathbb{R}}$, Schaan, Liechtenstein). The participants were divided in groups with the following treatments: group A $(n=14)$ : single application of $1 \%$ CHX varnish; group B $(n=14): 1 \%$ CHX varnish was applied once daily on three consecutive days; group $\mathrm{C}(\mathrm{n}=15): 1 \% \mathrm{CHX}$ varnish was applied 3 times with an interval of four days between each application; and group D $(n=12)$ : placebo varnish (without CHX and thymol) was applied once daily on three consecutive days. All participants were selected from a public school and had access to fluoridated public water supply (0.7 ppm F) and fluoride dentifrice (1500 ppm F). The study was approved by the Ethics Committee of the Faculty of Dentistry of the Federal University of Rio Grande do Su (protocol number 08/04). All participants' parents signed an informed consent.

Prior to varnish application, the teeth were professionally cleaned, the interdental areas were flossed, each quadrant was isolated with cotton rolls and dried. The varnish was then applied on all teeth surfaces using a small brush supplied by the manufacturer. The patients were instructed to avoid eating for $3 \mathrm{~h}$ and brushing their teeth for $24 \mathrm{~h}$, in accordance with the manufacturer's instructions.

Dental biofilm samples were collected at baseline and 1, 4 , and 8 weeks after the final varnish application. Subjects were asked to refrain from oral hygiene of the posterior teeth $48 \mathrm{~h}$ before the sampling. Dental biofilm samples were collected with a sterile curette along the supragingival margins of posterior tooth surfaces (labial, lingual, and interdental sites). All analyses were blindly performed by the same researcher.

Dental biofilm was dehydrated in a vacuum desiccator over phosphorus pentoxide $\left(\mathrm{P}_{2} \mathrm{O}_{5}\right)$ and the dry weight was obtained $( \pm 0.01 \mathrm{mg}$, Sartorius BP $210 \mathrm{D}$, Sartorius, Goettingen, Germany). For inorganic phosphate $\left(\mathrm{P}_{\mathrm{i}}\right)$ and insoluble polysaccharide (IP) analysis, $0.5 \mathrm{M}$ hydrochloric acid $(\mathrm{HCl})$ was added to the microtube $(0.1 \mathrm{~mL} \mathrm{HCl} / \mathrm{mg}$ dry weight dental biofilm). After $3 \mathrm{~h}$ at room temperature under constant agitation, the same volume of TISAB II pH 5.0 (containing $20 \mathrm{~g} \mathrm{NaOH} / \mathrm{L}$ ) was added as a buffer. The samples were centrifuged for $10 \mathrm{~min}$ at $14000 \mathrm{rpm}$ (Eppendorf 5410, Eppendorf AG, Hamburg, Germany) and the supernatant retained for determination of $\mathrm{P}_{\mathrm{i}}$. To the precipitate, $1.0 \mathrm{M}$ $\mathrm{NaOH}(0.2 \mathrm{~mL} / \mathrm{mg}$ dry weight plaque) was added. After $3 \mathrm{~h}$ at room temperature under constant agitation, the samples were centrifuged and the concentration of IP was determined in the supernatant (17). $\mathrm{P}_{\mathrm{i}}$ was determined colorimetrically (18) and IP was determined using the phenolsulfuric method (19).

The $\mathrm{P}_{\mathrm{i}}$ and IP concentrations were evaluated using ANOVA for repeated measures and a Tukey test using SAS version 9.1 (SAS, Cary, North Carolina, USA). The level of significance was set at $5 \%$.

\section{Results}

The results were expressed as micrograms of inorganic phosphate per milligram of dental biofilm $\left(\mu \mathrm{g} \mathrm{P}_{\mathrm{i}} / \mathrm{mg}\right.$ dental biofilm) and micrograms of insoluble polysaccharide per milligram of dental biofilm ( $\mu \mathrm{g}$ IP/mg dental biofilm). 
Table 1. Mean \pm standard deviation of inorganic phosphate concentration in dental biofilm at baseline (BL) and 1,4 , and 8 weeks after different $1 \%$ CHX varnish regimens and placebo varnish application ( $\mu \mathrm{g}_{\mathrm{i}} / \mathrm{mg}$ dental biofilm).

Table 2. Mean \pm standard deviation of insoluble polysaccharide concentration in dental biofilm at baseline (BL) and 1,4 , and 8 weeks after different $1 \% \mathrm{CHX}$ varnish regimens and placebo varnish application ( $\mu \mathrm{g}$ IP/mg dental biofilm).

\begin{tabular}{ccccc}
\hline Group* $^{*}$ & $\mathrm{BL}$ & $1 \mathrm{wk}$ & $4 \mathrm{wk}$ & $8 \mathrm{wk}$ \\
\hline $\mathrm{A}$ & $6.63 \pm 4.73^{\mathrm{Ba}}$ & $10.19 \pm 6.28^{\mathrm{Aa}}$ & $7.59 \pm 4.83^{\mathrm{Ba}}$ & $6.33 \pm 2.58^{\mathrm{Ba}}$ \\
$\mathrm{B}$ & $7.57 \pm 3.62^{\mathrm{Ba}}$ & $10.40 \pm 8.09^{\mathrm{Aa}}$ & $7.06 \pm 3.42^{\mathrm{Ba}}$ & $7.78 \pm 4.82^{\mathrm{Ba}}$ \\
$\mathrm{C}$ & $5.56 \pm 2.41^{\mathrm{Ba}}$ & $8.05 \pm 5.57^{\mathrm{Aa}}$ & $7.78 \pm 4.15^{\mathrm{Ba}}$ & $6.58 \pm 2.55^{\mathrm{Ba}}$ \\
$\mathrm{D}$ & $7.63 \pm 5.98^{\mathrm{Ba}}$ & $10.16 \pm 6.29^{\mathrm{Aa}}$ & $7.65 \pm 7.74^{\mathrm{Ba}}$ & $7.50 \pm 4.45^{\mathrm{Ba}}$ \\
\hline
\end{tabular}

* Group A: 1 varnish application; group B: once daily, 3 consecutive days; group C: 3 times, at 4-day intervals; group D: placebo varnish. Means followed by different capital letters (line) and small letters (column) differ significantly, ANOVA for repeated measures and Tukey test $(P<0.05)$.

\begin{tabular}{ccccc}
\hline Group* $^{*}$ & $\mathrm{BL}$ & $1 \mathrm{wk}$ & $4 \mathrm{wk}$ & $\mathbf{w k}$ \\
\hline $\mathrm{A}$ & $44.66 \pm 21.69^{\mathrm{Aa}}$ & $38.79 \pm 20.73^{\mathrm{Ba}}$ & $32.08 \pm 9.71^{\mathrm{Ca}}$ & $37.90 \pm 9.74^{\mathrm{BCa}}$ \\
$\mathrm{B}$ & $47.42 \pm 9.77^{\mathrm{Aa}}$ & $44.18 \pm 11.16^{\mathrm{Ba}}$ & $30.12 \pm 12.76^{\mathrm{Ca}}$ & $36.08 \pm 9.04^{\mathrm{BCa}}$ \\
C & $50.63 \pm 17.15^{\mathrm{Aa}}$ & $39.81 \pm 17.34^{\mathrm{Ba}}$ & $32.37 \pm 11.29^{\mathrm{Ca}}$ & $33.49 \pm 10.83^{\mathrm{BCa}}$ \\
D & $50.86 \pm 12.00^{\mathrm{Aa}}$ & $35.75 \pm 9.47^{\mathrm{Ba}}$ & $27.67 \pm 9.40^{\mathrm{Ca}}$ & $28.05 \pm 6.79^{\mathrm{BCa}}$ \\
\hline
\end{tabular}

* Group A: 1 varnish application; group B: once daily, 3 consecutive days; group C: 3 times, at 4-day intervals; group D: placebo varnish. Means followed by different capital letters (line) and small letters (column) differ significantly, ANOVA for repeated measures and Tukey test $(P<0.05)$.
At baseline, there was no statistically significant difference of $\mathrm{P}_{\mathrm{i}}$ and IP between the groups in the dental biofilm. After 1 week, a significant increase in $\mathrm{P}_{\mathrm{i}}$ concentration was observed in all groups (A, B, C, and D), returning to baseline values after 4 weeks. No difference was observed between all groups during the different experimental periods (Table 1).

All groups showed a significant decrease in IP concentrations for more than 8 weeks after treatment. No difference was observed between all groups during the different experimental periods (Table 2).

\section{Discussion}

The present study was performed to investigate the effect of different regimens of a varnish containing $1 \% \mathrm{CHX}$ on the biochemical composition of dental biofilm. The $\mathrm{P}_{\mathrm{i}}$ and IP concentrations were evaluated. Three regimens were tested: (i) single application; (ii) once daily application, on three consecutive days; (iii) 3 applications with an interval of four days between each. No difference in the biochemical composition of the dental biofilm could be observed between the different groups. Treatment with placebo and CHX varnish demonstrated the same effect on $\mathrm{P}_{\mathrm{i}}$ and IP concentrations. All treatments showed a transitory increase in the $\mathrm{P}_{\mathrm{i}}$ biofilm concentration and a decrease in the IP biofilm concentration.

The presence of MS in dental biofilm has been used as an indicator of cariogenic biofilm $(4,5)$. Studies that evaluated $\mathrm{CHX}$ have used the levels of MS to investigate its cariogenic effect $(9,11,12,16)$. In relation to $1 \% \mathrm{CHX}$ varnish, considering the microbiological aspects, there is no consensus in the literature on the ideal regimen. It has been applied in intensive modes with 2-3 applications within a 2 -week period $(9,14,20)$ or once a month $(15,20)$. Intensive short-term 1\% CHX gel application (3-4 daily applications on two consecutive days) (11) showed MS reduction similar to less intensive treatment for a prolonged period of time (10-14 days) $(21,22)$. Frequent CHX administration has been justified by the speculation that a repeated consecutive treatment strategy could increase the suppressive effect on MS levels by inhibiting re-growth. As a consequence, it would favor tooth surface colonization by other microorganisms, promoting modifications in the cariogenicity of the dental biofilm.

Few studies have been conducted to compare 1\% CHX varnish regimens $(12,23)$. Although Twetman and Petersson (12) have suggested that intensive treatment is more effective in reducing MS, Ribeiro et al. (23) have observed that repeated applications of $1 \% \mathrm{CHX}$ varnish do not increase its effects and $1 \% \mathrm{CHX}$ varnish caused a slight, short-term reduction in MS levels.

Most studies have evaluated the effect of $\mathrm{CHX}$ on the microbiological composition of the dental biofilm (24). However, it has been suggested that the structure of the biofilm formed can be more relevant than the number of cariogenic microorganisms with respect to caries development (8). The inorganic composition of the dental biofilm (calcium, inorganic phosphate, fluoride) is important in the equilibrium between demineralization and remineralization of enamel. The presence of IP in the dental biofilm increases its porosity and favors the adherence and accumulation of microorganisms on the tooth surface. The cariogenicity of the dental biofilm has been correlated with the IP (25). Cury et al. (7) demonstrated that the dental biofilm formed in the presence of sucrose showed higher IP and lower inorganic concentration, suggesting that these are the characteristics of a cariogenic dental biofilm. The present study demonstrated a significant alteration in biochemical composition of the 
dental biofilm with an increase in the $\mathrm{P}_{i}$ concentration 1 week after the treatments. The source of this additional amount of $\mathrm{P}_{\mathrm{i}}$ found in the dental biofilm is from oral environment, because the saliva is supersaturated with respect to enamel mineral (calcium and inorganic phosphate). These ions are important to maintain the environment supersaturated when biofilm $\mathrm{pH}$ falls. These ions can diffuse from saliva to biofilm forming a mineral reservoir, making this biofilm less cariogenic $(7,25)$.

The literature shows that there is a close relation between concentrations of $\mathrm{Ca}$ and $\mathrm{P}_{\mathrm{i}}$. When low concentration of $\mathrm{Ca}$ is observed, simultaneously a low concentration of $\mathrm{P}_{\mathrm{i}}$ is also verified $(7,25)$. Therefore the analysis of the only one ion $\left(\mathrm{P}_{\mathrm{i}}\right)$, performed in this study, was adequate to indicate a low inorganic composition of the dental biofilm.

High concentration of insoluble polysaccharides in dental biofilm may increase its porosity and cariogenicity $(26,27)$. In the present study, a significant decrease in IP concentrations for more than 8 weeks after treatments was verified in the dental biofilm. These results suggest a change in the biofilm extracellular matrix, which contains polysaccharides, reducing its cariogenicity.

However, these modifications were also observed in the group treated with the placebo varnish, without the two active components (thymol and $\mathrm{CHX}$ ). These results suggest that another component present in the varnish could be influencing the alterations of the biochemical composition of the dental biofilm and this effect could not be attributed to the active components $\mathrm{CHX}$ and thymol. The data of the three experimental groups show an increase in $\mathrm{P}_{i}$ levels and decrease in IP levels after varnish treatment. One could conclude from these results that the $\mathrm{CHX}$ varnish decreased the cariogenicity of the dental biofilm. However, analyzing these data together with the control group, no difference was observed between the groups

\section{Conclusion}

The present study demonstrated that varnish application resulted in modification of the dental biofilm toward a less cariogenic one.

\section{Acknowledgements}

This study was supported by a grant from the Coordenação de Aperfeiçoamento do Pessoal de Nível Superior (CAPESBrazil) and Fundação de Amparo à Pesquisa do Estado do Rio Grande do Sul (FAPERGS/0412881).

The authors thank the schoolchildren and their parents for their valuable participation. Thanks to Ivoclar-Vivadent (Schaan, Lichtenstein) for the supply of Cervitec ${ }^{\circledR}$ and placebo varnish.

This manuscript is derived from a thesis submitted by the first author to the Faculty of Dentistry, UFRGS (Porto Alegre, RS, Brasil) as a partial fulfillment of the requirements for the Master's Degree in Clinical Dentistry. children highly infected with mutans streptococci. Scand J Dent Res 1989;97:330-7.

2. van Rijkom HM, Truin GJ, van 't Hof MA. A meta-analysis of clinical studies on the cariesinhibiting effect of chlorhexidine treatment. J Dent Res 1996;75:790-5.

3. Zickert I, Emilson CG, Krasse B. Effect of caries preventive measures in children highly infected with the bacterium Streptococcus mutans. Arch Oral Biol 1982;27:861-8.

4. Loesche WJ. Role of Streptococcus mutans in human dental decay. Microbiol Rev 1986;50:353-80.

5. van Houte J. Role of micro-organisms in caries etiology. J Dent Res 1994;73:672-81.

6. Emilson CG. Susceptibility of various microorganisms to chlorhexidine. Scand J Dent Res 1977;85:255-65.

7. Cury JA, Rebello MA, Del Bel Cury AA. In situ relationship between sucrose exposure and the composition of dental plaque. Caries Res 1997;31:356-60.

8. Mattos-Granner RO, Smith DJ, King WF, Mayer MPA. Water-insoluble glucan synthesis by mutans streptococcal strains correlates with caries incidence in 12- to 30-month-old children. J Dent Res 2000;79:1371-7.

9. Twetman S, Petersson LG. Comparison of the efficacy of three different chlorhexidine preparations in decreasing the levels of mutans streptococci in saliva and interdental plaque. Caries Res 1998;32:113-8.

10. Hoffmann T, Bruhn G, Richter S, Netuschil L, Brecx M. Clinical controlled study on plaque and gingivitis reduction under long-term use of low-dose chlorhexidine solutions in a population exhibiting good oral hygiene. Clin Oral Investig 2001;5:89-95.

11. Maltz M, Zickert I, Krasse B. Effect of intensive treatment with chlorhexidine on number of Streptococcus mutans in saliva. Scand J Dent Res 1981;89:445-9.

12. Twetman S, Petersson LG. Effect of different chlorhexidine varnish regimens on mutans streptococci levels in interdental plaque and saliva. Caries Res 1997;31:189-93.

13. Balanyk TE, Sandham HJ. Development of sustained-release antimicrobial dental varnishes effective against Streptococcus mutans in vitro. J Dent Res 1985;64:1356-60. 
14. Ekenback SB, Linder LE, Lonnies $\mathrm{H}$. Effect of four dental varnishes on the colonization of cariogenic bacteria on exposed sound root surfaces. Caries Res 2000;34:70-4.

15. Joharii RM, Adenubi JO. Prevention of pit and fissure caries using an antimicrobial varnish: 9 month clinical evaluation. J Dent 2001;29:247-54.

16. Ribeiro LGM, Hashizume LN, Maltz M. The effect of different formulations of chlorhexidine in reducing levels of mutans streptococci in the oral cavity: A systematic review of the literature. J Dent 2007;35:359-70.

17. Pecharki GD, Cury JA, Paes Leme AF, Tabchoury CP, Del Bel Cury AA, Rosalen PL, et al. Effect of sucrose containing iron (II) on dental biofilm and enamel demineralization in situ. Caries Res 2005;39:123-9.

18. Fiske CM, Subarrow Y. The colorimetric determination of phosphorus. Arch Oral Biol 1970;15:1069-77.

19. Dubois M, Grilles KA, Hamilton JK, Rebers PA, Smith F. Colorimetric method for determination of sugars and related substances. Anal Chem 1956;28:350-6.

20. Haukali G, Poulsen S. Effect of a varnish containing chlorhexidine and thymol (Cervitec) on approximal caries in 13- to 16-year-old schoolchildren in a low caries area. Caries Res 2003;37:185-9.

21. Clark DC, Morgan J, MacEntee MI. Effects of a $1 \%$ chlorhexidine gel on the cariogenic bacteria in high-risk elders: a pilot study. Spec Care Dentist 1991;11:101-3.

22. Emilson CG. Effect of chlorhexidine gel treatment on Streptococcus mutans population in human saliva and dental plaque. Scand J Dent Res 1981;89:239-46.

23. Ribeiro LGM, Hashizume LN, Maltz M. Effect of different $1 \%$ chlorhexidine varnish regimens on levels of mutans streptococci in saliva and dental biofilm. Am J Dent 2008;21:295-9.

24. Twetman S, Petersson LG. Efficacy of a chlorhexidine and a chlorhexidine-fluoride varnish mixture to decrease interdental levels of mutans streptococci. Caries Res 1997;31:361-5.

25. Cury JA, Rebello MA, Del Bel Cury AA, Derbyshire MT, Tabchoury CP. Biochemical composition and cariogenicity of dental plaque formed in the presence of sucrose or glucose and fructose. Caries Res 2000;34:491-7.

26. Dibdin GH, Shellis RP. Physical and biochemical studies of Streptococcus mutans sediments suggest new factors linking the cariogenicity of plaque with its extracellular polysaccharide content. J Dent Res 1988;67:890-5.

27. Zero DT. In situ caries models. Adv Dent Res 1995;9:214-30. 